\title{
Identity and Knowledge Production in the Fourth Generation
}

\author{
Nana Akua Anyidoho*
}

\begin{abstract}
This paper examines the linked themes of identity and knowledge production embedded within the concept of insider scholarship. Insider scholarship may be described as the production of knowledge by a scholar about a group with which s/he identifies as a member. We are immediately compelled to complicate this definition by asking how any such group is delineated and how membership therein shapes knowledge production. The idea of insider scholarship thus evokes a series of queries about who produces what knowledge, about whom and for whom. The paper makes the argument that the discussion on insider scholarship has gained renewed relevance. In an effort to reclaim representations of Africa and Africans, earlier generations of African scholars might sometimes have based scholarly legitimacy on idealisations of race, culture and territory. From that historical point, we appear to be in a moment when notions of 'cosmopolitanism' and 'universalism' make nonsense of any attempt to ground scholarship in complex and shifting identities. As the fourth generation of scholars comes into its own, one of its defining tasks will be to negotiate this contested terrain. This paper represents such an attempt. It argues that the concept of insider scholarship cannot simply be discarded as irrelevant. To do so would constitute an ill-advised neglect or woeful ignorance of the politics of representation about Africa, and of the power differentials in different spaces within the field of African Studies. However, there are multiple grounds for claiming 'insiderness', and defining it by narrow parameters is unhelpful, if not damaging to any sense of common purpose. In light of this, I present 'shared struggle' as a strategic basis for reconstituting the theoretical value and the viable practice of insider scholarship. I conclude the paper by examining the implication of this conceptual shift.
\end{abstract}

\section{Résumé}

Cet article examine les thèmes liés de l'identité et de la production de connaissances ancrés dans le concept de savoir d'initié. Le savoir d'initié peut être décrit comme la production de connaissances par un chercheur sur un

* Institute of Statistical, Social and Economic Research (ISSER), University of 
groupe auquel il/elle s'identifie comme membre. Nous sommes immédiatement obligés de rendre complexe cette définition en nous demandant comment un tel groupe est déterminé et comment l'adhésion à ce groupe influence la production de connaissances. L'idée de savoir d'initié évoque ainsi une série de questions sur celui qui produit quel type de connaissance, sur qui et pour qui. L'article soutient que le débat sur le savoir d'initié a gagné une pertinence renouvelée. Les premières générations de chercheurs africains, dans un effort de reprise des représentations de l'Afrique et des Africains, auraient parfois fondée la légitimité intellectuelle sur des idéalisations de race, de culture et de territoire. De ce point historique, nous semblons vivre une période où les notions de «cosmopolitisme» et d'«universalisme » rendent absurde toute tentative de fonder le savoir sur des identités complexes et changeantes. Pendant que la quatrième génération de chercheurs se dessine, une des tâches visant à la définir sera de négocier ce terrain contesté. Cet article est une tentative dans cette perspective. Il soutient que la notion de savoir d'initié ne peut pas simplement être considérée comme impertinente. Le faire constituerait une négligence inconsidérée ou une ignorance déplorable des politiques de représentation de l'Afrique, ainsi que des rapports de pouvoir qui régissent les différents espaces des Etudes africaines. Toutefois, il existe plusieurs raisons de demander une «initiation», et définir celle-ci par des paramètres étroits est inutile, voire préjudiciable à toute notion de but commun. Par conséquent, je présente la «lutte partagée» comme une base stratégique pour la reconstitution de la valeur théorique et la pratique viable du savoir d'initié. Je conclus cet article en examinant les implications de ce changement conceptuel.

\section{Introduction}

This paper asks the question, 'What is African in African Studies' or, phrased differently, 'where is the African in the study of Africa?' What is the linkor should there be a link? Between location and scholarship, between belonging and knowledge production, between identity and representation? This question, long a subject, sometimes a subtext, of debate, is not one we can afford to dismiss as we look back over the state of knowledge production about Africa, in order that we may chart new courses.

Why are identity and knowledge production issues for a new generation of African scholars? It is not because they are novel concerns, but precisely because they are perpetual challenges that require every generation to offer responses peculiar to its circumstances. Let me refer to an incident at a CODESRIA Symposium on Canonical Works and Continuing Innovation in the African Arts and Humanities held in Accra in 2003 to make the point. A paper had just been presented on the politics of representation of Africa in US academia. Another participant quickly stood up to question the relevance of what goes on in the US to scholarship produced on and about the continent, suggesting clearly that this was a preoccupation that we (as African 
scholars) could well do without. Without placing too much of a burden of proof on this incident, it did serve as a powerful reminder of the generational standpoints that Mkandawire (1995) refers to in his typology of African scholar(ship).

The author of the paper whose relevance was called into question was a younger scholar working in the US. For him, these issues of representation in US academia arguably had personal and immediate resonance. The questioner was an older colleague based on the continent. The latter had the profile of a member of the third generation whom Mkandawire describes as primarily homegrown, and who lack the impulse of the immediate predecessors generation to 'speak back', or to defend its scholarship to non-African arbiters. It may be that the older scholar's comment was an expression of a generational orientation. In the same way, the paper presenter may have been attempting to map out the terrain for the scholarship of his generation. The concerns raised by his paper, while of varying personal interest to his audience, do reflect the general truth that scholarly work about Africa is impacted, as well, by factors 'extraneous' to the continent, and even more so in an increasingly globalized era. The intimate nature of today's society demands attention to events on one end of the world that may have a ripple effect on the other end. The events of the past few years alone have proven that we cannot afford to think of 'the global village' as merely a cliché. Again, as bilateral and multilateral agencies move away from obviously coercive modes of Structural Adjustment to more subtle, but perhaps even more effective control strategies, the local becomes integrated perforce into the global. Alongside these trends are theoretical perspectives that laud the fusion of ideas and cultures. It is imperative that we maintain an awareness of the confluence of political, social, economic and ideological forces that influences our scholarship.

How, then, do we take account of and draw on the 'global' to re-envision an African Studies that is firmly situated in Africa? The importance of this question is highlighted by my very use of the term 'African Studies'. This paper gives it the commonsense meaning of the gamut of intellectual production about Africa. However, the label has taken on a peculiar slant, denoting an area of knowledge in Western educational institutions removed from the 'mainstream', and housed in specific programmes (see Murunga in this volume). By contrast, there are few programmes or research centres on the continent that bear the nomenclature 'African Studies', except perhaps in South Africa and a few selected countries. In fact, one could argue that much of the knowledge produced in African academic institutions falls into African Studies by virtue of content and standpoint. Yet it appears power is 
located elsewhere and determines the nature of available knowledge about the continent. This ultimately influences the way that Africa is engaged by the global community. ${ }^{1}$ It is in the context of this reality that I introduce the idea of insider scholarship as a way of balancing locations of power in African Studies.

\section{From Where Do We Speak? Questions of Location and Positionality}

Insider research can be understood as the practice of research within a group with which one self-identifies as a member. This definition, however, belies the many meanings that are brought to bear on the term, and the contestations around who belongs to what group.

The idea of identity at the heart of this article references the related concepts of location and positionality. Positionality refers to the identities of the researcher in relation to the 'researched' (Wolf 1996). In other words, positionality indicates contextualised and relational locations such as nationality, ethnicity, race, class, education, religion, family affiliation, ideological leanings, epistemological perspectives and philosophical orientations. Positionality is contextual because it takes account of the circumstances in which knowledge is produced, and relational because it concerns both the subjectivity of the researcher and the subjectivities of others. ${ }^{2}$

Positionality is an important concept because it has implications for the nature of knowledge produced, and how that knowledge is received. This is a truth that has been painfully self-evident in writing about Africa. Positioning themselves as missionaries or administrators, non-Africans made representations about Africans from self-declared locations of authority. Those representations were validated by non-African audiences (and even by African readers privy to these works) because they came supposedly from 'enlightened' sources speaking on behalf of those incapable of speaking for themselves. One reaction of African scholars to this untenable state of affairs was to claim that we could produce similarly 'worthwhile' scholarship despite the fact that we were Africans. A second response was the attempt to reclaim representations of ourselves by asserting that our scholarship was legitimate precisely because we were African. It is this second rationale that has buttressed the practice of insider scholarship.

\section{Unpacking 'Insider Scholarship'}

Insider scholarship has been around for a long time under many names: indigenous ethnography, auto-ethnography, insider research, native research, endogenous research, research competence by blood, introspective research, 
etc., (cf. Messerschmidt 1981; Reed-Danahay 1997). It is noteworthy that many of these designations come from the field of anthropology, which has been in the eye of the conceptual storm around insider scholarship. Anthropology has been marked conventionally by its study of 'Other' cultures. What happens then when the anthropological gaze is turned inwards, when the other becomes the researcher or, in Kenyatta's words, when a rabbit turns poacher? (Kenyatta 1992 [1938]: xviii). The blurring of the lines between researcher and subject has led to much angst in anthropology, and has resulted in wider interdisciplinary discussions. The field of African Studies has been powerfully impacted by this debate because of the importance of anthropology as a foundational discipline in African Studies programmes.

Insider scholarship is not a new practice, therefore. What has changed are the terms of the debate. When, in 1981, the anthropologist John Aguilar made his well-cited contribution to a book on the subject of insider research, he acknowledged the near-crisis point to which the increased incidence of insider research had brought his discipline. Aguilar attempted to take stock of this trend, presenting a painstaking tally of the relative merits and demerits of 'outsider' and 'insider' research. The essential criterion was how each 'method' could help or hinder objective, unbiased, scientific research. Aguilar concluded his lengthy examination with a few paragraphs querying the notion of an absolute insider or outsider. By contrast, there is now increased emphasis on the epistemological and political dimensions of insider research, rather than on methods and technique. To illustrate, a relatively more recent set of essays on auto-ethnography (Reed-Danahay 1997) speaks extensively regarding the difficulty of defining national, ethnic, racial or geographic memberships, and thoughtfully explores the impact of complex and dynamic identities on scholarly activity.

A major catalyst for insider scholarship is the general disaffection with positivism. A corresponding embrace of subjectivity opens up representation to interrogation. The point has been increasingly brought home that, to an extent, all representations are interpretations. We can no longer assume that one person, using 'scientific' methods, can get at the 'Truth'. What we have, rather, are versions of truths told from different viewpoints or positions.

The theoretical development that problematises representations as a function of identity is powerful because it immediately creates space for multiple representations. Feminists and post-colonialists, for instance, can juxtapose old representations with new ones from the margins (Gandhi 1998). In this way, insider scholarship can be used strategically as a tool to counter colonising representations of non-Western subjects (Narayan 1997), which are 
often the basis for political and economic exploitation. Research by 'natives', 'indigenes' and former 'Others' is thus situated within the larger sociopolitical project of decolonisation and self-determination.

The contours of the theoretical and political move towards self-representation were traced out in the years when African nations were celebrating or anticipating their release from the moorings of direct colonial domination; the opportunity for self-definition - for a deliberate construction and dissemination of self-representations - was a giddy prospect. Identity became an oft-visited site of analysis. The goal was to either fashion new identities, or to reclaim pre-existing ones, to counteract the hegemonic presence of the 'European' image. One example, perhaps overused because of its salience, is that of Negritude. While Negritude can be described in a number of ways, fundamentally, it sought to affirm a distinctive African way of being that was set up in opposition to the (perception) of the Europeans'. In other words, the proponents of Negritude aimed to present a set of representations about Africans created from an 'authentic' location.

For those who engage in this admittedly political project of self-representation, the aim is not to collect varied representations, but to replace 'harmful' representations with more realistic, more 'authentic' accounts from the 'inside'. And yet the very paradigm that makes room for different representations is at the same time an obstacle to this political end: If representation is mere interpretation, as some would contend, then can one be more 'right', more 'true' than another? And if there are no fixed identities, can one make claim to an inviolable insider status as validation for one's representations?

\section{Critiques of Insider Scholarship}

Over time, other orientations have emerged that proclaim that there is no best location to produce knowledge; that rather there exist multiple, equally viable locations. Ideological perspectives such as universalism, cosmopolitanism and Créolité have been proposed as more useful and accessible metaphors for identity, and more encompassing of the contradictions of contemporary life. These approaches do not attempt to tie Self to race, ethnicity, language, or culture. Rather than opposing tradition to modernity, the urban to the rural, and the African to the European, 'identity is destabilised and de-essentialised and rendered heterogeneous, plural and uncertain' (Lewis 1998). ${ }^{3}$

From these and similar perspectives, the first objection to the idea of insider scholarship is that it promotes a totalising conception of identity. A related critique is that scholarship based on race, geography, nationality, ethnicity, gender, etc., is essentialist and essentialising. Thirdly, insider scholar- 
ship is opposed on the grounds that it gives credence to the very Self-Other distinctions that it tries to question. I will respond to these objections briefly here, and then more fully in the next section where I argue for a rethinking of insider scholarship.

The first point to be made is that there is a growing realisation that people constantly negotiate various identities in the ordinary business of living. Consequently the insider-outsider dichotomy is necessarily de-emphasised in favour of an understanding that every researcher is simultaneously an insider and an outsider in any research situation (Zavella 1996). The claim to insider status must, therefore, be indexed for context to prevent it from becoming totalising. It should be used as a marker of one's location in a carefully delineated research situation.

The second critique suggests that the very idea of formulating an insider identity with respect to a societal, national, cultural or other grouping runs the risk of essentialising that group. However, this is not necessarily problematic if we realise that all social categories we appeal to are essentialist in that they are social and historical constructions (Fuss 1989). The real question is not the nature of these categories but the ends to which they are put. Fabien Eboussi Boulaga states that 'race is not a logical or scientific problem, but a political problem in search of an absolute, metaphysical justification' (quoted in Mafeje 2000). We can add that geography, nationality, gender, and ethnicity are similarly political, and can be selectively retained for their political utility.

Finally, the charge that insider scholarship reinforces homogeneous stereotypes of the native, the indigene and the Other/Object (Lal 1996) is perhaps the most damning for African scholars who would want to envisage their work as a way of deconstructing colonial images of their people. A quick dismissal of insider research on these grounds alone is either a facile denial of differences in location, or a wilful ignorance of the politics of the production and use of knowledge. If subscribing to an insider status is reminiscent of colonial notions of Self and Other, it is because those distinctions do exist, have been perpetuated, and would continue to operate even if African researchers chose to ignore them. A more practical response to this political reality is to strategically occupy those locations in order to reconstitute them.

It is important to point out that this debate about the value of insider scholarship is not mere abstraction, or simply an opportunity to score academic points. It is fundamentally a political question, as Narayan (1997) implies when she observes that discussions about identity and representation can be wielded strategically either to empower or disempower scholarship. Insider scholarship is most commonly associated with Western-dominated 
academic spaces, into which the insider is allowed so that she may represent her people to Western audiences. Such a strong link is assumed between the scholar and 'her' grouping that she is seen as speaking for others, in which case a specific national/cultural/ethnic/gendered identity may be highlighted to give the greatest credence to her representations. ${ }^{4}$ In such an instance, the question is not how good her representations are, but how good a representative she is judged to be by her audience (Narayan 1997).

In a paradoxical manner, the insider is at one and the same time privileged as the voice of many others and marginalised by having her scholarship constrained to the local and the specific. Some African scholars may revel in the status of the resident Insider, while others resist the label, repudiating all ties to any one group so they may speak more 'universal' truths. Under these circumstances, the critiques of insider scholarship appear to have merit: Insider scholarship does indeed become totalising, essentialist and stereotypical in assuming a unitary location for the scholar, and in encouraging uni-dimensional representations of a people. It is my argument that the theory and practice of insider scholarship can be redeemed from such unfavourable associations.

\section{Re-centring Insider Scholarship}

The common charges levelled against insider scholarship are based on assumptions about audience, about the purpose of scholarship, and about locations of power. I propose a redefinition of insider scholarship that takes into account these elements of audience, purpose and power.

Insider scholarship has often been preoccupied with re-representing 'insiders' to 'outsiders'. One definition of insider scholarship has it as:

a text in which people undertake to describe themselves in ways that engage with representations others have made of them ... [T] hey involve a selective collaboration with and appropriation of idioms of the metropolis or conqueror. These are merged or infiltrated to varying degrees with indigenous idioms to create self-representations intended to intervene in metropolitan modes of understanding (Pratt 1994: 28, quoted in Reed-Danahay 1997: 7-8, emphasis mine).

The political aspect of insider scholarship is clearly acknowledged in the above statement. However, the single-minded goal Pratt advocates of 'infiltrating' or injecting our ideas into the 'metropolis' only endorses the dominance of that which it seeks to topple. I find such scholarship inconsistent with the political end of self-representation. I am advocating an adjustment in perspective so that insider scholarship is not used principally to indicate one's relationship to supposedly more powerful Western audiences. 
In the task of orienting itself to better negotiate a new era, the fourth generation has to balance the respective outward and inward orientations of the second and third generations (Mkandawire 1995). Our ambition cannot be merely to speak (back) to an outside audience. Insider scholarship should be local scholarship in terms of its reference points. The local should be the focus of our scholarship - as its audience, its primary beneficiaries, and its agenda setters. In this way, we gradually move power back to the centre. On the other hand, centring African Studies on Africa and Africans does not mean a neglect of the global currents of ideas, or of the imbalance of power. The move to the centre is a crucial starting point [see also Mwangola's emphasis on moving from the periphery to the centre in this volume]. A necessary and complementary move is from the centre outward.

\section{'Shared Struggle' as a Basis for Insider Scholarship}

I offer the idea of shared struggle as a means of realising the potential of insider scholarship while avoiding its pitfalls. 'Situated knowledge' is a useful foundational concept, in that it acknowledges differentiated locations, and affirms these locations as starting points for the production of knowledge. From the foregoing, the question of where you stand is important, because every research project, and indeed all scholarship, has its basis in the personal. ${ }^{5}$ Locations are, however, mobile because each person inhabits multiple locations within and across time. To avoid an identity trap, the question of what you stand for should be as important as where you stand. In this way, a discursive space can be created for 'an imagined community of ... intellectuals that rise above national, racial, and gendered boundaries in the articulation of politically responsible representations' (Lal 1996: 200). Mohanty similarly appeals to the notion of imagined communities of resistance, proposing that

it is not colour or sex which constructs the grounds for these struggles. Rather it is the way we think about race, class and gender - the political links we choose to make among and between struggles. Thus, potentially, [scholars] of all colours ... can align themselves with and participate in these imagined communities. However, clearly our relation and centrality in particular struggles depend on our different ... locations and histories [Mohanty 1991: 4, emphasis mine].

The last sentence, without prejudice to what precedes it, does imply that the ability to be engaged in a particular struggle — and even our understanding of what the struggle is about-is influenced by experiences of gender, class, geography, class, race, etc. As Mkandawire advises, while one would want to encourage mutual respect and a sense of 'a community of scholars work- 
ing on Africa', the power relations underlying knowledge production about Africa continue to keep African scholarship and African scholars outside of the centre. Mkandawire proposes that by 'sheer numbers, existential interest and proximity to the reality, African scholars will play an important role in the generation of knowledge about Africa' (1997: 35). I suggest that an 'existential' interest connotes lived experience which, while not synonymous with 'biology or physical location' (Asante 1997), frequently correlates with such demographic characteristics. It is difficult for someone with an existential interest in the continent to give up on African Studies (and, I suppose, on Africans) as one Africanist scholar famously declared he has done. ${ }^{6}$ Existential interest, or lived reality, is likely to inform a commitment to a certain kind of scholarship: 'Because we are all, researchers and subjects, the products of our history and culture, an experience of social and political exclusion is likely to shape more critical thinking and writing about such experiences in the collective, structural domain' (Motzafi-Haller 1997: 217).

In sum, while a particular background may make certain types of scholarship more likely, there is a level of choice. It is not the mere fact of 'native' birth that is important, but rather the connection we make between our experiences and our research. In other words, the idea of shared struggle respects nationality, geography, race, gender, etc., but does not make these labels the sole basis on which scholarship is evaluated.

\section{How Does all this Relate to the Practice of Scholarship?}

To leave this discussion at a rhetorical level, without having it inform the way we conduct our work as scholars, would be unhelpful. What I present here are ideas that bear reflecting on, not as a one-time exercise, but as an integral part of our scholarship over time. I call for greater self-reflexivity.

Collins (2002) maintains the need for the scholar - especially one who is in a position of marginality - to map a personal epistemology for her work. At various points in our careers, and for specific research ventures, we should ask ourselves: 'On what basis do I claim insider status?' In my own case, if I call myself an insider as I conduct research on low-income, rural Ghanaian women, I am saying that my positionality within that defined context, at that particular time, is that of someone who by lived experience and by shared interests is a member of a delimited group. I am 'claiming a genealogical, cultural and political set of experiences' (Smith 1999: 12) that I consider to be the basis of my research. But again, we have to allow that others in the research context also define our positionality. Personally, I have to recognise the ways in which I may be considered an outsider by the women I do my research among; the ways in which they would highlight aspects of 
my identity (such as education, urban residence, socioeconomic status) which I choose to make secondary to my 'genealogical, cultural and political' locations. In other research contexts, there might be a differential emphasis placed on each of these identities. It is the context that defines what being an insider is, rather than some prior label, and it is important that we be attentive to how the constant shift of positionality (that is, of identity in relation to location) impacts our scholarship.

Again, scholarship based on shared struggle implies that research is political both in intent because it is value-driven, and in effect because representations have consequences. It has often been said of African scholars that we do not have the luxury of doing 'mere' academic research. I dare say this is not a condition of African scholarship alone. It may be more accurate to say that perhaps Africans, for the reasons discussed in this article, need be more self-conscious about the fact that research is a political exercise.

Finally, the idea of insider scholarship as shared struggle means that research should be inclusive. It cannot be an imposition of one's agenda on others. The struggle itself, as I have stated, has to be a process of negotiation. ${ }^{7}$ It is recognising that the presuppositions, the ideas, interests and values that we invariably enter into research with, may not be those of the people with whom we do research. I am mindful of this in my own work because of my presumption to speak on behalf of 'my' research participants. My research agenda is motivated by dissatisfaction with development paradigms that are applied, sometimes indiscriminately, by our governments and by international development agencies. I am wary of the harm they cause when they do not take into account the context of people's lives. My research project is being carried out in the obvious hope that it will influence policy making. Therein lies the danger. If the targets of these programmes do not share my critical perspective, do I put down their non-participation in my struggle as evidence of false-consciousness? Can I come out of the research experience having taken on their struggle-even if their struggle involves strengthening the very programmes I critique in my research? Since insider research attempts to represent both the struggle and those involved in it, it is representation both in the sense of speaking about and speaking for. Alcoff cautions that 'the practice of speaking for others is often born of a desire for mastery, to privilege oneself as the one who more correctly understands the truth about another's situation' (1991: 29). This is an indictment we should avoid if we intend to engage in scholarship that affirms African peoples as centres of power and knowledge. Self-reflexivity is always key. 


\section{Conclusion}

I conclude this paper by reiterating the value of insider scholarship for a new generation of scholars. The locations to which insiders lay claim do not make them better scholars (Anyidoho 1983) or necessarily lead them to present their conditions and those of others in a more reliable manner. A badge of 'insiderness' cannot replace critical analysis or be a cloak of immunity to having one's representations challenged (Narayan 1997). However, with self-reflexivity and with intentionality, insider scholarship can be an important basis of knowledge production.

\section{Acknowledgment}

An earlier version of article appears as a chapter in Intellectuals and African Development: Pretension and Resistance in African Politics (Zed Books, 2006). I am indebted to Mshai Mwangola, Ato Kwamena Onoma, David Donkor, and Godwin Murunga for their investment in this article, through challenge and encouragement.

\section{Notes}

1. For a useful analysis of power dynamics in globalised academia, see David Slater's, 'Challenging Western Visions of the Global: The Geo-Politics of Theory and North-South Relations', European Journal of Development Research, Vol. 7, no. 2, 1995, pp. 366-388.

2. It is important to note that the identity of the scholar is informed not only by her own self-identification but also by the identities imposed on her by the circumstances of, and the people involved in, the process of knowledge production. While acknowledging that one's identities are not wholly selfdetermined, for the purposes of this particular discussion I foreground that aspect of positionality that is somewhat within the conscious decision-making of the scholar.

3. Lewis was speaking in specific reference to Créolité but the statement holds true for similar orientations to the question of identity, that oppose what they would perceive as the essentialisation of identity and, by extension, the production of knowledge on such grounds.

4. Alternatively, aspects of a researcher's identity may be used to devalue her work, as may happen when she is charged with not being an 'authentic' representative of 'her' people. De-authentication is equated with 'westernisation', which is evidenced by formal schooling, high socioeconomic status, residence outside of one's home country, etc. As Linda Smith (1999) points out, this is a disingenuous practice by which our scholars are accused of being disenfranchised and therefore incapable of relevant representations, while the 'indigenous' people are dismissed for lacking the conversance with 
the discourse of academia to speak for themselves. Who then can speak? Smith asks.

5. Much of what we identify as our research agendas derive from questions that we have a personal interest in finding answers to, phenomena that fascinate us, and points we want to prove. There is no such thing as disinterested research.

6. I received the text of Gavin Kitching's 'Why I gave up African Studies' through African Studies related listservs, where it was widely circulated. I understand that he presented a version of the paper at the African Studies Conference in Adelaide, Australia in 2000. As much controversy as this declaration stirred, it should not have shocked those who have read Paul Tiyambe Zeleza brilliant satire of an uncannily similar scenario in Manufacturing African Studies and Crises. For further debate on Kitching's papers, see African Studies Quarterly, Vol. 7, no. 2 \& 3, Fall 2003 at http://web.africa.ufl.edu/asq/index.htm

7. I credit David Donkor with this insight.

\section{References}

Abu-Lughod, L., 1988, 'Fieldwork of a Dutiful Daughter', in Soraya Altorki and Camillia Fawzi El-Solh, eds., Arab Women in the Field: Studying Your Own Society, Syracuse: Syracuse University Press.

Aguilar, J., 1981, 'Insider Research: An Ethnography of a Debate', in Donald Messerschmidt, ed., Anthropologists at Home in North America: Methods and Issues in the Study of One's Own Society, Cambridge: Cambridge University Press.

Alcoff, L., 1991, 'The Problem of Speaking for Others', Cultural Critique 08824371, pp.5-32.

Anyidoho, K., 1983, 'Death and Burial of the Dead: A Study of Ewe Funeral Folklore', Unpublished Masters Thesis, University of Indiana.

Appiah, K., 1997, 'Cosmopolitan Patriots', Critical Inquiry, Vol. 23, no. 3.

Asante, M. K., 1997, 'More Thoughts on the Africanists' Agenda', Issues, Vol. 23, no. 1, pp.11-12.

Collins, P. H., 2002, Black Feminist Thought: Knowledge, Consciousness and the Politics of Empowerment (2nd Edition), New York: Routledge.

Diagne, S. B., 1993, 'The Future of Tradition', in Momar Coumba Diop, ed., Senegal: Essays in Statecraft, Dakar: CODESRIA.

Fonow, M. M. and Cook, J. A., eds., 1991, Beyond Methodology: Feminist Scholarship as Lived Research, Bloomington: Indiana University Press.

Fuss, D., 1989, Essentially speaking: Feminism, nature and difference, New York and London: Routledge.

Gandhi, L., 1998, Postcolonial theory: A critical introduction, New York: Columbia University Press.

Kenyatta, J., 1992 [1938], Facing Mount Kenya, Nairobi: Kenway Publications. 
Lal, J., 1996, 'Situating Locations: The Politics of Self, Identity, and "Other" in Living and Writing the Text', in D. L. Wolf (ed.), Feminist Dilemmas in Fieldwork, Boulder, CO: Westview Press.

Lewis, S.K., 1998, 'From Négritude to Créolité: Race, Culture and Identity in Francophone West African and Caribbean Literature and Theory', Unpublished Ph.D. Thesis, Duke University.

Mafeje, A., 2000, 'Apropos African Modes of Self-Writing: Adieu Mbembe', in Southern African Political and Economic Monthly (SAPEM), Vol. 13, no. 12.

Mbembe, A., 2000, 'African Modes of Self-Writing', CODESRIA Bulletin, Vol. 1, pp.4-19.

Messerschmidt, D., ed., 1981, Anthropologists at Home in North America: Methods and Issues in the Study of One's Own Society, Cambridge: Cambridge University Press.

Mkandawire, T., 1995, 'Three Generations of African Scholars: ANote', CODESRIA Bulletin, No. 2.

Mkandawire, T., 1997, 'The Social Sciences in Africa: Breaking Local Barriers and Negotiating International Presence', The Bashorun M.K.O. Abiola Distinguished Lecture presented to the 1996 African Studies Association Annual Meeting, African Studies Review, Vol. 40, no. 2, pp.15-36.

Mohanty, C. T., 1991, 'Cartographies of struggle: Third World Women and the Politics of Feminism', in Chandra T. Mohanty, Ann Russo and Lourdes Torres, eds., Third World Women and the Politics of Feminism, Bloomington: Indiana University Press.

Mohanty, C. T., 2002, 'Under Western Eyes Revisited. Feminist Solidarity through Anticapitalist Struggle', Signs: Journal of Women in Culture and Society, Vol. 28, no. 2, pp.499-535.

Motzafi-Haller, Pnina, 1997, 'Writing Birthright: On Native Anthropologists and the Politics of Representation', in Deborah E. Reed-Danahay, ed., Auto/ Ethnography: Rewriting the Self and the Social, Oxford: Berg.

Murunga, G., 2004, 'Mbembe's 'African Modes of Self-Writing' and the Critics in Public Culture', CODESRIA Bulletin, nos. 1 \& 2, pp. 27-32.

Narayan, K., 1993, 'How Native is a "Native" Anthropologist?', American Anthropologist, Vol. 95, pp.671-686.

Narayan, U., 1987, 'The Project of Feminist Epistemology: Perspectives from a Non-Western Feminist', in Alison M. Jaggar and Susan R. Bordo, eds., Gender/ Body/Knowledge: Feminist Reconstructions of Being and Knowing, New Brunswick, N.J.: Rutgers University Press.

Narayan, U., 1997, Dislocating Cultures: Identities, Traditions, and Third-World Feminism, New York: Routledge.

Obbo, C., 1990, ‘Adventures with Fieldnotes', in Roger Sanjek, ed., Fieldnotes. Ithaca: Cornell University Press.

Pratt, M. L., 1992, Imperial Eyes: Travel Writing and Transculturation, London and New York: Routledge. 
Reed-Danahay, D. E., 1997, 'Introduction', in Deborah E. Reed-Danahay, ed., Auto/ Ethnography: Rewriting the Self and the Social, Oxford: Berg.

Rosenau, P. M., 1992, Post-modernism and the Social Sciences: Insights, Inroads, and Intrusions, Princeton, NJ: Princeton University Press.

Slater, D., 'Challenging in Western Visions of the Global: The Geo-Politics of Theory and North-South Relations,' in European Journal of Development Research, Vol. 7, no. 2, 1995, pp. 366-388.

Smith, L. T., 1999, Decolonizing Methodologies: Research and Indigenous Peoples, London: Zed Books Ltd.

wa Thiong'o, N., 1993, Moving the Centre: The Struggle for Cultural Freedoms, London: Heinemann.

Wolf, D. L., 1996, 'Situating Feminist Dilemmas in Fieldwork', in Diane L. Wolf, ed., Feminist Dilemmas in Fieldwork, Colorado: Westview Press.

Zavella, P., 1996, 'Feminist Insider Dilemmas: Constructing Ethnic Identity with Chicana Immigrants', in Diane L. Wolf, ed., Feminist Dilemmas in Fieldwork, Colorado: Westview Press.

Zeleza, P. T., 1997, Manufacturing African Studies and Crises, Dakar: CODESRIA. 